Review

\title{
Toward an Understanding of Family Business Sustainability: A Network-Based Systematic Review
}

\author{
He Soung Ahn ${ }^{1}\left(\mathbb{D}\right.$, EuiBeom Jeong ${ }^{2} \mathbb{D}$ and Hyejin Cho ${ }^{2, * \mathbb{C}}$ \\ 1 Department of Business Administration, Sejong University, Seoul 05006, Korea; hsahn@sejong.ac.kr \\ 2 Department of Business Administration, Korea University, Anam-ro 145, Seoul 02841, Korea; \\ euibeom@korea.ac.kr \\ * Correspondence: hyejinstory@korea.ac.kr; Tel.: +82-10-7136-3581
}

check for

updates

Citation: Ahn, H.S.; Jeong, E.; Cho, $\mathrm{H}$. Toward an Understanding of Family Business Sustainability: A Network-Based Systematic Review. Sustainability 2021, 13, 5. https:/ /dx. doi.org/10.3390/su13010005

Received: 24 November 2020 Accepted: 17 December 2020 Published: 22 December 2020

Publisher's Note: MDPI stays neutral with regard to jurisdictional claims in published maps and institutional affiliations.

Copyright: () 2020 by the authors. Licensee MDPI, Basel, Switzerland. This article is an open access article distributed under the terms and conditions of the Creative Commons Attribution (CC BY) license (https: / / creativecommons.org/ licenses/by/4.0/).

\begin{abstract}
Family business governance is an important issue for the sustainable development of economies worldwide due to its economic contribution. This review aims to offer a systematic overview of how prior studies explore the issue of family involvement within the broader corporate governance literature. By adopting a network-based perspective to visualize the research stream, this study provides meaningful insight into the key topics investigated, the patterns in the connections between critical papers, and the key players building the literature. Specifically, this paper makes three major contributions. First, our systematic review based on network analysis of keywords, citations, and authors enhances the understanding of how research on family involvement in the corporate governance literature is interconnected. Second, a large and extensive pool of corporate governance research on family involvement (947 papers) is employed to encompass research on family involvement from various academic disciplines under the umbrella of corporate governance. Third, by providing answers to questions such as "which journals should I read?", "which keywords should I look for?", "who are the leading scholars?", "which journals are scholars publishing in?" and "what are emerging research trends?", this study offers valuable implications for future research and meaningful guidelines for future studies in the field.
\end{abstract}

Keywords: family governance; corporate governance; keyword network analysis; citation network analysis; author network analysis

\section{Introduction}

Firms that are characterized by family governance through ownership and control are ubiquitous in many countries, including both emerging markets [1,2] as well as developed markets [3-5]. Not only are these family businesses a predominant form of corporate governance in the economic landscape around the world [6]; they also make a significant contribution to economic and social sustainability $[7,8]$. According to the Family Firm Institute [9], two-thirds of corporations around the world are owned and managed by families, which contributes to approximately 70 to 90 percent of annual global gross domestic production (GDP). Although family businesses are unique in terms of how they are governed in making decisions and achieving goals [10], they have been proven to be a consistently sustainable organizational form. As the family governance literature has now reached a level of maturity in which a review of the relevant literature is timely, there have been a number of reviews on family businesses. However, existing reviews either (1) generally survey family firm research as a unique academic field to provide an overview of the topics studied or methodologies adopted [11-14] or (2) narrowly focus on a particular dimension of family firms such as succession [15,16], internationalization [17], philanthropy [18], entrepreneurship [19], accounting practices [20], or institutional contexts $[21,22]$. Despite these existing attempts, there are several limitations to existing review attempts. First, there is still a critical lack of a broader understanding about how knowledge 
in the family governance literature accumulated and evolved over time. Second, many reviews have a narrow scope as they either focus on a specific topic or chosen journal outlets that are pre-selected. Third, reviews that do not rely on a systematic methodology tend to depend on authors' judgements [23-25] and thus limit our understanding of the research network that formed naturally. While the authors' own interpretation of the literature may provide a unique literature review, our approach has an advantage in identifying the underlying relationship among literature.

As a critical gap exists in our understanding of how governance issues are addressed in family business literature, we suggest that a rigorous scientific review of research on family business literature with a special focus on corporate governance is in demand. This is not simply because of the sufficient abundance of prior research related to family governance warrants such a review [26]. Given that new ideas must build on existing knowledge $[27,28]$, an understanding of the social structure of shared knowledge is imperative to elicit meaningful insights and implications for sustainable family businesses [28]. In this review, we aim to visualize the knowledge networks that are manifested in the existing literature by combining the well-established systematic review approaches (i.e., popularity-based and network-based approaches) to draw a better understanding of the knowledge networks of the family governance literature. In analyzing the knowledge network in the family business governance literature, we utilize three elements of papers, i.e., keywords, citations, and authors, rather than focusing on a single element. By doing so, meaningful insight into the key topics explored (i.e., keyword network), the patterns in the links between key papers (i.e., citation network), and the main researchers building the literature (i.e., author network) are identified. To the best of our knowledge, no study has attempted to conduct such a comprehensive systematic review of the family governance literature.

The remainder of the paper is structured as follows. Section 2 presents an overview of the keyword network analysis. Section 3 introduces the structured methodology used to identify and further refine the literature reviewed and evaluated in this study. This section also presents some general observations and detailed analysis. Finally, Section 4 summarizes the results, presents the limitations of this study, and discusses opportunities for future research.

\section{Review Methodology}

\subsection{Literature Review on Review Methods}

Once a research stream matures to a certain degree, scholars turn their attention to conducting reviews of the literature that has been built up to date [29]. By evaluating and plotting a body of literature, scholars can not only synthesize individual research endeavors but also identify potential research gaps and highlight the boundaries of contemporary knowledge $[30,31]$. By doing so, advancement in research can be stimulated and foundations for the sustainable development of the research stream can be laid out [25]. Accordingly, numerous researchers adopted various empirical approaches to conduct such literature reviews.

The popularity-based approach, which includes analytic techniques derived from bibliometric analysis, examines papers' titles and keywords in terms of their frequency in publications [32]. For instance, Rey-Martí, et al. [33] conducts a bibliometric analysis of social entrepreneurship research to present the popular research topics, frequency of language used in publications, annual distribution of publications, popular journal outlets, and popular researchers in the field. De Bakker, et al. [34] conducts a bibliometric analysis of the academic literature on corporate social responsibility and corporate social performance to evaluate the popularity of various elements (e.g., journals, authors, words, and word pairs used in the title), and the frequency of different epistemological orientations (e.g., theoretical, prescriptive). López-Fernández, et al. [35] uses bibliometric indicators (e.g., activity indicators such as the volume of research and relation indicators such as cocitations) to review the research trend of entrepreneurship in family firms. 
Another review methodology relies on a network-based approach that uses citations and co-citations to investigate relationships among published papers and authors [28,36]. Both citation and co-citation rely on the assumption that authors cite relevant articles that they consider to be important for developing their research [29]. As a basic citation analysis identifies the citation frequency of articles, it shows the popularity of the focal article [37]. On the other hand, co-citation analysis constructs co-citation networks that is characterized by a set of nodes (i.e., publications) and a set of links (i.e., co-citation relationships) [36]. Papers that are frequently co-cited indicates that their contents are similar [38]. For instance, Ramos-Rodríguez and Ruíz-Navarro [29] use citation and co-citations to analyze the intellectual structure of strategic management research. Shiau, et al. [39] and Culnan [40] examine the co-citation relationships in leading journals in the management information systems (MIS) field in order to show the internal relationships among pairs of papers that are co-cited and to uncover subfields in which research is most active. Relatedly, Nerur, Rasheed and Natarajan [23] uses authors as the unit of analysis to visualize the network structure of influential authors in the strategic management field. Pilkington and Meredith [41] reviews the operations management (OM) literature by examining what papers are actually cited (i.e., citation analysis) and the relationship between papers that are cited together (i.e., co-citation analysis).

Despite the merits of the existing empirical analysis for literature review, each has its own drawbacks. While the popularity-based approach can provide an overview of an intellectual field through frequency analysis [34,42], it cannot provide a structural insight into the connections among research. Hence, the popularity-based approach lacks a suggestion of strong or weak links in the literature and the boundary of important research interests in a given topic [28]. Even though the popularity of a published paper does not necessarily indicate its prestige [37], citation and co-citation analyses treat all articles as being equally important [24]. In addition, such an analysis based on a single factor (e.g., citation or author) limits our understanding of the landscape of literature as a whole.

Considering these drawbacks in existing approaches to systematic literature reviews, we adopt a more exhaustive and extensive network analysis approach to systematically review the family governance literature. In particular, we evaluate the keyword, citation, and author network of the family governance research. First, the keyword network is investigated because authors carefully select keywords that they consider to be representative of the core idea of a given research [43]. Thus, an investigation of the network of keywords allows us to gain insight into the important themes in the literature and existing relationships among influential papers. Second, we explore the citation network of family governance research. Rather than simply relying on citation frequency or co-citations, PageRank is used to incorporate both the popularity and the prestige of papers. PageRank is a link analysis method that examines the connections between nodes and measures the relative importance of each node within the group. PageRank measures the prestige of an article by identifying the frequency of citation by other highly cited articles [44]. Third, author network is examined in order to explore key actors that have contributed to the knowledge structure of the family governance literature. By assessing these linkages among studies in terms of keyword, citation, and author, we are able to understand the family governance literature from various angles.

\subsection{Data Collection}

We collected a comprehensive list of publications about the family business that were published between 1981 and 2019. In order to obtain a more comprehensive set of articles about firms with family governance, we adopted a relatively conservative approach by choosing those with and at least one family involvement-related keyword and at least one corporate governance-related keyword in the publication's title, abstract, or list of keywords [45]. Although existing reviews tend to preselect journals to examine $[24,28,29,39,41,46]$, our analysis does not limit publication outlets because the topic of family governance by nature 
is an interdisciplinary field of inquiry. As such, research on family governance is largely dispersed across various academic disciplines.

Table 1 summarizes the list of 6 corporate governance-related keywords and 24 family involvement-related keywords used for the analysis. To be included in the sample, the article should simultaneously have at least one keyword from "Family Involvement Keywords" and one from "Corporate Governance Keywords". After analyzing the keywords list of various journals, we found that some articles from finance journals does not directly include corporate governance in the keyword list and rather includes keywords such as agency theory or ownership because corporate governance is already assumed to be an important issue. Hence, we include ownership, ownership structure, and agency theory in the keyword list used for publication selection.

Table 1. Keyword list for publication selection.

\begin{tabular}{cc}
\hline $\begin{array}{c}\text { family, family controlled, family management, family enterprise, family } \\
\text { involvement, family business research, family business group, family } \\
\text { leadership, family SME(s), family ownership, family owner(s), } \\
\text { Keywords } \\
\text { family-ownership, family owned, family-owned, family firm(s), family } \\
\text { business(es), family corporation(s), family company(companies), } \\
\text { family-controlled, family control, controlling family, family member(s), } \\
\text { family manager(s), family-owned business enterprises }\end{array}$ \\
\hline $\begin{array}{c}\text { Corporate Governance } \\
\text { Keywords }\end{array}$ & $\begin{array}{r}\text { corporate governance, governance structure(s), governance, ownership, } \\
\text { ownership structure(s), agency theory }\end{array}$ \\
\hline
\end{tabular}

The final sample consists of 947 papers. Table 2 reports the list of journals with publications that account for at least 1 percent of the total of publications selected. Family Business Review publishes the most papers (133 papers out of 927 papers) relating to family governance, which accounts for 14.03 percent of our sample. Journal of Family Business Strategy and Corporate Governance: An International Review follows closely behind, with each publishing 83 and 50 articles, respectively. The top ten journals comprise a total of $51.37 \%$ among all publications of our sample, which suggests that research on family firms are dispersed across various journal outlets. Figure 1 presents the distribution of publications by year. Although research on family governance has existed as early as 1981, there is an increasing trend of interest in the field.

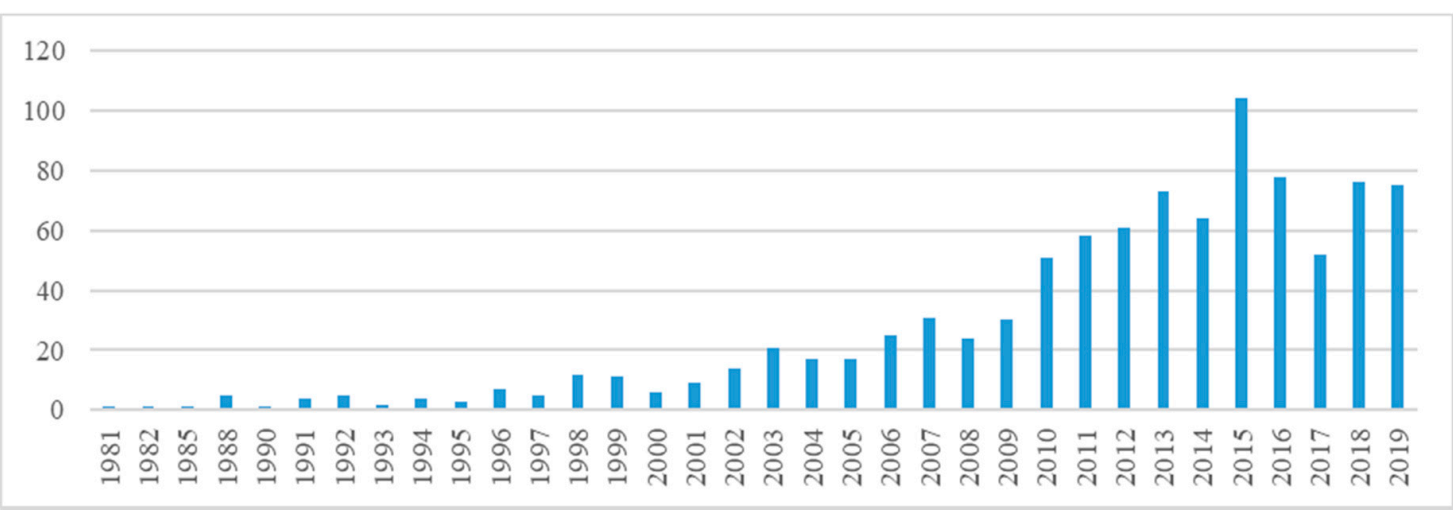

Figure 1. Yearly distribution of publications (1981-2019). 
Table 2. Journals by Number of Publications.

\begin{tabular}{cccc}
\hline Rank & Journal & Publications & Ratio \\
\hline 1 & Family Business Review & 133 & $14.03 \%$ \\
2 & Journal of Family Business Strategy & 83 & $8.76 \%$ \\
3 & Corporate Governance: An International & 50 & $5.27 \%$ \\
4 & Review & 39 & $4.11 \%$ \\
5 & Journal of Business Research & 35 & $3.69 \%$ \\
6 & Small Business Economics & 34 & $3.59 \%$ \\
7 & Entrepreneurship: Theory and Practice & 32 & $3.38 \%$ \\
8 & Journal of Small Business Management & 28 & $2.95 \%$ \\
9 & Asia Pacific Journal of Management & 28 & $2.95 \%$ \\
10 & Journal of Corporate Finance & 25 & $2.64 \%$ \\
11 & Journal of Business Ethics & 18 & $1.90 \%$ \\
12 & Business History & 16 & $1.69 \%$ \\
13 & Journal of Financial Economics & 15 & $1.58 \%$ \\
14 & Journal of Business Venturing & 13 & $1.37 \%$ \\
15 & International Business Review & 13 & $1.37 \%$ \\
16 & Journal of Management and Organization & 13 & $1.37 \%$ \\
17 & Strategic Management Journal & 12 & $1.27 \%$ \\
18 & Management Decision & 10 & $1.05 \%$ \\
\hline
\end{tabular}

\section{Network Analysis of the Family Governance Literature}

\subsection{Keyword Network Analysis}

We conducted a keyword network analysis based on 1471 keywords to uncover the important keyword lists of the three different network measures for (1) the full sample, (2) the top three journals, and (3) the main theories. The full sample shows the overall trend of corporate governance research related to family involvement. The keyword network analysis for selected journals provides evidence on the differences among important outlets, while the analysis for the main theories can improve our understanding of the important theoretical lenses.

Prior to constructing the keyword network, we refined a list of keywords to address non-standardized keywords. As authors can use different keywords to refer to the same issue or concept, we processed the initial group of keywords by changing keywords with fundamentally the same meaning to the same standard word. The rules for refinement included standardization of multiple words into a single form, removing redundant keywords, removing hyphens, avoiding abbreviations, unifying synonyms, and separating multiple terms in a single keyword. After the standardization, we conducted a keyword network analysis using NetMiner, a network analysis tool that facilitates the analysis of both network and unstructured text data through various analytical data handling strategies.

Table 3 reports the total number of keywords as well as the density, distance, and clustering coefficients of the keyword network. Density measures the proportion of actual connections in a network relative to the number of connections possible. The density of a network relies on the size of the network; a large network is generally less dense. The distance of a network refers to the average number of steps along the shortest paths for all pairs of network keywords (i.e., nodes), revealing the degree of efficiency of information in a network. The clustering coefficient describes the degree of connectivity between neighboring keywords in a network, reflecting the ratio of the number of existing keyword links to the total possible links among keywords. For the keyword network constructed, the density (0.006) and clustering (0.006) coefficients are low, indicating a relatively large and not a highly clustered network. At the same time, long distance (2.595) and the low density of the network structure (0.006) implies that family governance research covers various research ideas or topics. 
Table 3. Structural characteristics of the keyword network.

\begin{tabular}{ccccc}
\hline & Keywords & Density & Distance & Clustering Coefficient \\
\hline All & 1471 & 0.006 & 2.595 & 0.006 \\
\hline
\end{tabular}

We followed the network literature to identify lists of important keywords for three different types of network centrality: degree centrality, betweenness centrality, and closeness centrality [47-50]. Each network centrality measure captures the different aspect of each keyword in the keyword network. First, degree centrality is the number of word connections that the node has, which reflects the intensity of word usage. A highly ranked keyword has many relationships with other keywords. Second, betweenness centrality measures the extent to which a keyword is located in the paths between other keywords [51,52]. Hence, a keyword that scores high on betweenness centrality acts as a point of control that connects keyword groups with different characteristics. Since such a keyword bridges a subset of keywords, deleting it from a keyword network would diminish the coherency of the keyword network. Thus, a keyword can score high on betweenness centrality even though it is not highly connected to other keywords in each cluster of keywords [28]. Finally, closeness centrality measures the number of keywords, on average, a focal keyword passes to reach all keywords in the network. That is, closeness centrality is the total geodesic distance from a focal keyword to all other keywords [53]. A keyword that is high on closeness centrality provides a higher level of access efficiency in the network [54].

Table 4 presents the top keywords regarding the degree, betweenness, and closeness centrality. Given that degree centrality is the number of word connections of a node, the top ten keywords in terms of degree centrality are highly connected to other keywords in the literature and represent the major research interests in the field. The top 10 keywords in terms of betweenness centrality bridge the distinctive research themes. The top 10 keywords in terms of closeness centrality are located in the center of the keyword network. The list of important keywords for different types of network centrality share most of the same keywords, such as "family firm," "corporate governance," "family ownership," "agency theory," "socioemotional wealth perspective," "ownership structure," "ownership," and "family control." Unsurprisingly, "family firm," "family ownership," or "corporate governance" appeared as the top five keywords because most of the research covers the issue of family governance. Notably, "corporate social responsibility (CSR)" did not appear within the top 10 keywords in terms of degree centrality; it was the last among the top 10 keywords in terms of betweenness centrality and closeness centrality. This result implies that while the use of "corporate social responsibility" is not as intense, it still has power in linking other concepts and we can consider it to be one of the major focuses of research. For instance, Terlaak, et al. [55] finds that CSR performance depends on the level of family control in business group firms because of socioemotional wealth concerns.

Table 4. Top Ten Keywords in the Keyword Network.

\begin{tabular}{cccc}
\hline Rank & Degree Centrality & Betweenness Centrality & Closeness Centrality \\
\hline 1 & family firm & family firm & family firm \\
2 & corporate governance & corporate governance & corporate governance \\
agency theory \\
3 & agency theory & family ownership & performance \\
4 & family ownership & agency theory & family ownership \\
5 & performance & performance & ownership structure \\
6 & socioemotional wealth perspective & socioemotional wealth perspective & socioemotional wealth perspective \\
7 & ownership structure & ownership structure & family control \\
8 & ownership & ownership & family control \\
9 & governance & corporate social responsibility & corporate social responsibility \\
\hline
\end{tabular}


We show five important keywords in the keyword network measures for the top three journals based on the number of published papers in Table 5. While the analysis above indicates the overall importance of a keyword, three journals also show similarities and differences. In Family Business Review, "socioemotional wealth perspective" is a very important concept as it appears in all three network measures. As noneconomic factors collectively termed "socioemotional wealth" are often recognized as an important feature that distinguishes family firms from nonfamily firms, it is not surprising that family business research widely adopts the socioemotional wealth perspective in explaining the uniqueness of family involvement and that the non-economic benefits that families pursue in making strategic decisions relate directly to corporate governance issues $[56,57]$. The Journal of Family Business Strategy also shows similar results. The socioemotional wealth perspective is valued in closeness centrality. In betweenness centrality, "psychological ownership" is an important keyword. Similar to the socioemotional wealth perspective, psychological ownership draws on the psychology literature and explains the unique attributes of family involvement [58]. Since Corporate Governance: An International Review has general corporate governance or family firm-related keywords in all three types of centrality, it seems to publish research on a wide variety of topics related to family firms' corporate governance (such as "crisis" in Minichilli, et al. [59] and Crespí-Cladera and Martín-Oliver [60]) to the extent that these research interests cannot form an integrated keyword network. Additionally, agency theory is one of the most important theories in the Journal of Family Business Strategy and Corporate Governance: An International Review. Although agency theory as a keyword has many connections with other keywords in the Journal of Family Business Strategy, it does not necessarily bridge separate research themes, nor is it located in the center of the keyword networks.

Table 5. Top five keywords in the keyword network of the top three journals.

\begin{tabular}{|c|c|c|c|c|}
\hline Journal Title & Rank & Degree Centrality & Betweenness Centrality & Closeness Centrality \\
\hline \multirow{5}{*}{$\begin{array}{c}\text { Family Business } \\
\text { Review }\end{array}$} & 1 & family firm & family firm & family firm \\
\hline & 2 & agency theory & agency theory & agency theory \\
\hline & 3 & performance & performance & performance \\
\hline & 4 & socioemotional wealth perspective & socioemotional wealth perspective & socioemotional wealth perspective \\
\hline & 5 & corporate governance & corporate governance & ownership \\
\hline \multirow{5}{*}{$\begin{array}{l}\text { Journal of Family } \\
\text { Business Strategy }\end{array}$} & 1 & family firm & family firm & family firm \\
\hline & 2 & family ownership & family ownership & performance \\
\hline & 3 & performance & corporate governance & family ownership \\
\hline & 4 & agency theory & performance & socioemotional wealth perspective \\
\hline & 5 & ownership & psychological ownership & ownership \\
\hline \multirow{5}{*}{$\begin{array}{c}\text { Corporate } \\
\text { Governance: An } \\
\text { International } \\
\text { Review }\end{array}$} & 1 & corporate governance & corporate governance & corporate governance \\
\hline & 2 & family firm & family firm & family firm \\
\hline & 3 & family ownership & family ownership & family ownership \\
\hline & 4 & agency theory & board of director & agency theory \\
\hline & 5 & family control & agency theory & family control \\
\hline
\end{tabular}

Table 6 presents the top keywords associated with each of the main theory clusters. Agency theory, stewardship theory, behavioral agency theory, and institutional theory are the theoretical frameworks that are most frequently adopted in family firm research [61-65]. Within each theoretical framework, the 10 search keywords most commonly associated with each theory were identified [35]. Few notable points are worthwhile to mention. First, our analysis shows that research that utilizes agency theory tends to be associated with stewardship theory. Although both agency theory and stewardship theory are often applied to explain the unique aspects of family firms, the two theoretical frameworks are considered as distinctive and opposing approaches to understanding the governance relationships and behaviors in family businesses [61]. Second, keywords related to innovation and entrepreneurship tend to be associated with studies that adopt stewardship theory as its main theory. Even though family firms are often perceived to be conservative, they represent a surprisingly large portion of the most innovative firms around the world [66]. As strategic decisions regarding innovation and entrepreneurship require a long-term perspective, 
studies explain this behavior by the presence of family members that act as stewards of the firm [67]. Third, keywords related to the management of family firms (e.g., CEO succession, nonfamily CEO, professionalization, CEO compensation) are associated with research adopting behavioral agency theory. Given that the behavioral agency theory predicts that family members' concerns for socioemotional wealth may lead to risk aversion especially with respect to strategic choices threatening family control [57,68], governance issues about CEO succession are a critical strategic decision because family members are known to possess a strong desire to maintain family control, which leads to intention for transgenerational control [69]. Fourth, keywords related to corporate governance issues that are particularly relevant to emerging economies tend to be associated with studies adopting institutional theory as the main theoretical framework. Since family firms are prevalent in emerging markets which is characterized by weak institutional environments [70], the presence of family members as majority shareholders creates unique governance problems such as principal-principal conflicts.

Table 6. Top 10 keywords within the main theory clusters.

\begin{tabular}{|c|c|c|c|c|c|c|c|}
\hline $\begin{array}{l}\text { Theory } \\
\text { Cluster }\end{array}$ & Top Keywords & $\begin{array}{l}\text { Theory } \\
\text { Cluster }\end{array}$ & Top Keywords & $\begin{array}{l}\text { Theory } \\
\text { Cluster }\end{array}$ & Top Keywords & $\begin{array}{l}\text { Theory } \\
\text { Cluster }\end{array}$ & Top Keywords \\
\hline \multirow{9}{*}{$\begin{array}{l}\text { agency } \\
\text { theory }\end{array}$} & $\begin{array}{l}\text { stewardship } \\
\text { theory }\end{array}$ & \multirow{9}{*}{$\begin{array}{l}\text { stewardship } \\
\text { theory }\end{array}$} & $\begin{array}{c}\text { family } \\
\text { performance }\end{array}$ & & professionalization & \multirow{9}{*}{$\begin{array}{c}\text { institutional } \\
\text { theory }\end{array}$} & \multirow{9}{*}{$\begin{array}{c}\text { value } \\
\text { family CEO } \\
\text { emerging } \\
\text { market } \\
\text { principal } \\
\text { principal } \\
\text { conflict } \\
\text { gender } \\
\text { diversity } \\
\text { corporate } \\
\text { restructuring }\end{array}$} \\
\hline & family firm & & $\begin{array}{c}\text { family } \\
\text { governance }\end{array}$ & & nonfamily CEO & & \\
\hline & governance & & governance & $\begin{array}{l}\text { behavioral } \\
\text { agency theory }\end{array}$ & CEO succession & & \\
\hline & $\begin{array}{l}\text { family business } \\
\text { group }\end{array}$ & & $\begin{array}{c}\text { family } \\
\text { management }\end{array}$ & & $\begin{array}{l}\text { initial public offering } \\
\text { underpricing }\end{array}$ & & \\
\hline & institution & & innovation & & CEO compensation & & \\
\hline & $\begin{array}{c}\text { institutional } \\
\text { theory }\end{array}$ & & $\begin{array}{l}\text { corporate en- } \\
\text { trepreneurship }\end{array}$ & & blockholder & & \\
\hline & family governance & & bifurcation bias & & initial public offering & & \\
\hline & $\begin{array}{c}\text { family } \\
\text { management }\end{array}$ & & national culture & & private family firm & & \\
\hline & $\begin{array}{l}\text { family ownership } \\
\text { family dynamics }\end{array}$ & & $\begin{array}{c}\text { France } \\
\text { nonfamily firm }\end{array}$ & & $\begin{array}{l}\text { resource based view } \\
\text { family involvement }\end{array}$ & & \\
\hline
\end{tabular}

\subsection{Citation Network Analysis}

We conducted citation network analysis to identify both the popularity and relative importance (i.e., prestige) of an article according to the number of citations of the paper received by other highly cited papers [36,71,72]. Based on the assumption that the connections between papers in the citation network constitute channels through which scientific knowledge is transformed [73], citation network analysis allowed us to identify key papers that are particularly influential in the family governance literature [74].

Among the 947 papers, 908 papers formed a meaningful citation network (Refer to Table 7). This result implies that papers in our sample are a good representation of the research on family governance. For the citation network constructed, the density coefficient $(0.010)$ is low, the distance coefficient (3.517) is high, and the clustering coefficient $(0.248)$ is high. This indicates that the citation network is relatively sparse, relatively large, and highly clustered.

Table 7. Structural characteristics of the citation network.

\begin{tabular}{ccccc}
\hline & Papers & Density & Distance & Clustering Coefficient \\
\hline All & 908 & 0.010 & 3.517 & 0.248 \\
\hline
\end{tabular}


In order to overcome the limitations of the citation analysis, we analyzed the citation network using the PageRank algorithm. The PageRank score of a paper in a network comprised of $N$ papers was computed with the following equation, where paper $A$ is cited by $n$ papers (i.e., $T_{1}, \ldots, T_{n}$ ) and parameter $d$ is a damping factor that refers to the fraction of random walks that continue to spread along with citations. Following the Google PageRank algorithm by Brin and Page [44], we set the parameter $d$ to 0.85 .

$$
\frac{(1-d)}{N}+d\left(\frac{\mathrm{PR}\left(T_{1}\right)}{\mathrm{C}\left(T_{1}\right)}+\cdots+\frac{\mathrm{PR}\left(T_{n}\right)}{\mathrm{C}\left(T_{n}\right)}\right)
$$

Table 8 lists the top five influential papers according to their PageRank score in the citation network of 908 papers. These influential papers identified by the Page Rank scores are important not only because of their frequent appearance on the reference list, but also because of their higher centrality in the citation network as they connect other important papers as well [71]. Morck, et al. [75] examines the relationship between family ownership and market valuation of the family firm, while Anderson and Reeb [7] examine the relationship between founding-family ownership and firm performance. Other influential papers provide significant evidence of family ownership in not only developed nations such as the U.S. but also in various national contexts such as East Asia $[3,76,77]$.

Table 8. Top five influential papers in the citation network.

\begin{tabular}{|c|c|c|c|}
\hline Title & Journal & Authors (Year) & PageRank \\
\hline $\begin{array}{l}\text { Managerial ownership of voting rights. A study of } \\
\text { public corporations with dual classes of common stock }\end{array}$ & $\begin{array}{l}\text { Journal of Financial } \\
\text { Economics }\end{array}$ & DeAngelo and DeAngelo (1985) & 0.0470 \\
\hline $\begin{array}{l}\text { Management ownership and market valuation: An } \\
\text { empirical analysis }\end{array}$ & $\begin{array}{l}\text { Journal of Financial } \\
\text { Economics }\end{array}$ & Morck, Shleifer, and Vishny (1988) & 0.0351 \\
\hline Corporate ownership around the world & The Journal of Finance & $\begin{array}{l}\text { La Porta, Lopez-De-Silanes, and } \\
\text { Shleifer (2002) }\end{array}$ & 0.0288 \\
\hline $\begin{array}{l}\text { Founding-family ownership and firm performance: } \\
\text { Evidence from the S\&P } 500\end{array}$ & The Journal of Finance & Anderson and Reeb (2003) & 0.0132 \\
\hline $\begin{array}{l}\text { The separation of ownership and control in East Asian } \\
\text { Corporations }\end{array}$ & $\begin{array}{l}\text { Journal of Financial } \\
\text { Economics }\end{array}$ & $\begin{array}{l}\text { Claessens, Djankov, and Lang } \\
\text { (2000) }\end{array}$ & 0.0128 \\
\hline
\end{tabular}

Lastly, we conducted a clustering analysis for the most cited publications. In order to include publications that are considered to be most cited among our sample, we select papers with an in-degree centrality value of over 0.2 . This clustering analysis was conducted using a list of publications that authors need to consider in order to increase the validity of the research idea. Table 9 presents the main clusters that are identified.

Table 9. Main clusters in the citation network.

\begin{tabular}{|c|c|c|c|c|}
\hline Cluster & Title & Authors & Year & Journal \\
\hline \multirow{3}{*}{1} & Corporate ownership around the world & La Porta, Lopez de Silanes, and Shleifer & 1999 & \multirow{3}{*}{$\begin{array}{l}\text { The Journal of Finance } \\
\text { Journal of Financial } \\
\text { Economics } \\
\text { Journal of Financial } \\
\text { Economics }\end{array}$} \\
\hline & $\begin{array}{l}\text { The separation of ownership and control in East Asian } \\
\text { Corporations }\end{array}$ & Claessens, Djankov, and Lang & 2000 & \\
\hline & The ultimate ownership of Western European corporations & Faccio and Lang & 2002 & \\
\hline \multirow{7}{*}{2} & $\begin{array}{l}\text { Founding-family ownership and firm performance: } \\
\text { Evidence from the S\&P } 500\end{array}$ & Anderson and Reeb & 2003 & The Journal of Finance \\
\hline & $\begin{array}{l}\text { How do family ownership, control and management affect } \\
\text { firm value? }\end{array}$ & Villalonga and Amit & 2006 & $\begin{array}{l}\text { Journal of Financial } \\
\text { Economics }\end{array}$ \\
\hline & $\begin{array}{l}\text { A neglected factor explaining family business success: } \\
\text { Human resource practices }\end{array}$ & Astrachan and Kolenko (1994) & 1994 & Family Business Review \\
\hline & The family business: Toward definitional clarity & Litz (1995) & 1995 & Family Business Review \\
\hline & $\begin{array}{l}\text { The determinants of executive compensation in } \\
\text { family-controlled public corporations }\end{array}$ & $\begin{array}{l}\text { Gomez-Mejia, Larraza-Kintana, and } \\
\text { Makri }\end{array}$ & 2003 & $\begin{array}{l}\text { Academy of } \\
\text { Management Journal }\end{array}$ \\
\hline & $\begin{array}{l}\text { Succession and nonsuccession concerns of family firms and } \\
\text { agency relationship with nonfamily managers }\end{array}$ & Chua, Chrisman, and Sharma & 2003 & Family Business Review \\
\hline & $\begin{array}{l}\text { Lost in time: Intergenerational succession, change, and } \\
\text { failure in family business }\end{array}$ & Miller, Steier, and Le Breton-Miller & 2003 & $\begin{array}{l}\text { Journal of Business } \\
\text { Venturing }\end{array}$ \\
\hline
\end{tabular}


Table 9. Cont

\begin{tabular}{|c|c|c|c|c|}
\hline Cluster & Title & Authors & Year & Journal \\
\hline \multirow{5}{*}{3} & $\begin{array}{l}\text { An empirical examination of ownership structure in family } \\
\text { and professionally managed firms }\end{array}$ & Daily and Dollinger & 1992 & Family Business Review \\
\hline & Toward a theory of agency and altruism in family firms & Schulze, Lubatkin, and Dino & 2003 & $\begin{array}{l}\text { Journal of Business } \\
\text { Venturing }\end{array}$ \\
\hline & Are family firms really superior performers? & $\begin{array}{l}\text { Miller, Le Breton-Miller, Lester, and } \\
\text { Cannella Jr }\end{array}$ & 2007 & $\begin{array}{l}\text { Journal of Corporate } \\
\text { Finance }\end{array}$ \\
\hline & $\begin{array}{l}\text { Socioemotional wealth and business risks in } \\
\text { family-controlled firms: Evidence from Spanish olive oil } \\
\text { mills }\end{array}$ & $\begin{array}{l}\text { Gomez-Mejia, Haynes, Núñez-Nickel, } \\
\text { Jacobson, and Moyano-Fuentes }\end{array}$ & 2007 & $\begin{array}{l}\text { Administrative Science } \\
\text { Quarterly }\end{array}$ \\
\hline & $\begin{array}{l}\text { Socioemotional wealth and corporate responses to } \\
\text { institutional pressures: Do family-controlled firms pollute } \\
\text { less? }\end{array}$ & $\begin{array}{l}\text { Berrone, Cruz, Gomez-Mejia, and } \\
\text { Larraza-Kintana }\end{array}$ & 2010 & $\begin{array}{l}\text { Administrative Science } \\
\text { Quarterly }\end{array}$ \\
\hline
\end{tabular}

Cluster 1 mainly contains descriptive articles that explore the phenomenon of family governance and its implications for firm value. La Porta, Lopez-de-Silanes and Shleifer [3] compares the ownership structure of the largest publicly traded firms from 27 countries. Claessens, Djankov and Lang [77] examine the ownership and control patterns in 9 East Asian countries, while Faccio and Lang [5] examine that of corporations from 13 Western European countries. These three papers in cluster 1 focus on cross-national differences in the ownership and control patterns and identify family ownership as both prevalent and substantial. The remaining papers explore when family governance creates value for the family firm. Anderson and Reeb [7] find that not only do family firms perform better than nonfamily firms, their performance is likely to better when the firm is also managed by a family member. Villalonga and Amit [78] find that family ownership creates value when the founder is the CEO or the chairman of the board; interestingly, firm value is lower when a family descendant serves as CEO. Therefore, cluster 1 validates the phenomenon of family governance to be both prevalent and substantial around the world and its value-creating implications.

Cluster 2 focuses on the underlying factors beyond explicit ownership or control that contribute to family firm sustainability. Astrachan and Kolenko [79] suggest that the adoption of human resource management practices and professional governance practices is critical for the sustainability of the family business. Litz [80] proposes that the extent to which family members strive to achieve "intra-organizational family-based relatedness" is important for family firms' sustainable development. Finding that family CEOs are willing to accept lower executive compensation, Gomez-Mejia, et al. [81] emphasizes that altruistic family motives-which also become stronger at higher levels of family ownership concentration-contribute to family firm sustainability. Drawing on agency theory, Chua, et al. [82] find that relationships with nonfamily managers are important for sustaining family businesses. In a study of family firms that failed to achieve sustainability, Miller, et al. [83] outlines factors such as intergenerational family dynamics and inappropriate leadership styles as key sources. Overall, cluster 2 is interested in identifying various factors other than the concentration of ownership and/or management within the controlling family that contribute to the sustainability of family businesses.

Cluster 3 either compares different types of family businesses or family firms with their nonfamily counterparts in order to delineate the uniqueness of family governance. Focusing on business strategies, Daily and Dollinger [84] suggest that family firms that are managed by family firms tend to adopt a more conservative approach by avoiding growth-oriented strategies compared to their counterparts that are professionally managed. Schulze, et al. [85] draw attention to the unique agency relationships in family businesses that are characterized by altruism. Even if family agents are given performance-based incentive pay, family businesses have been found to experience agency problems that are difficult to mitigate [85]. Miller, et al. [86] investigates a more fine-grained measurement of family business (i.e., lone founder businesses vs. true family businesses) to provide a better understanding of whether family governance is beneficial or harmful for its 
sustainability; specifically, authors emphasize that market valuations depend greatly on how family businesses are defined. Gómez-Mejía, Haynes, Núñez-Nickel, Jacobson and Moyano-Fuentes [57] identify the loss of socioemotional wealth as the primary reference point that family businesses use to make decisions.

\subsection{Author Network Analysis}

Based on a list of 1670 authors that contributed to research on family governance in our sample of papers, we aimed to determine the important players are in the overall research stream by analyzing authors' names in the citations. We analyzed the authors' publication frequency and connections through the references. As Table 10 shows, the author network is relatively large but highly connected. The long distance (5.373) along with the high clustering coefficient (0.871) implies that while there is a highly connected network of authors that cover family involvement issues frequently, the sample contains many authors who published papers on family involvement less frequently.

Table 10. Structural characteristics of the author network.

\begin{tabular}{ccccc}
\hline & Authors & Density & Distance & Clustering Coefficient \\
\hline All & 1670 & 0.002 & 5.373 & 0.871 \\
\hline
\end{tabular}

In order to better understand the author network of the family governance literature, three network-related measures (i.e., degree centrality, betweenness centrality, and closeness centrality) were examined. Table 11 provides the top five contributors to the research stream in terms of frequency and each of the network-related measures. The top five influential authors by the number of publications are Miller D., Kellermanns F.W., Chrisman J.J., Le Breton-Miller I., and De Massis A. These top five authors contribute to nearly nine percent of the literature. The top two papers by the number of citations published by Miller D. with Le Breton-Miller I. are "Are family firms really superior performers?" published in the Journal of Corporate Finance, and "Why do some family businesses outcompete? Governance, long-term orientations, and sustainable capability" published in the Entrepreneurship: Theory and Practice. The focus of Miller D.'s family governance research provides meaningful evidence on the innovative outcomes and financial performance of family firms and the strategic choices of family founder/CEOs.

Table 11. Top five authors in the author network.

\begin{tabular}{ccccc}
\hline Rank & Frequency & Degree Centrality & Betweenness Centrality & Closeness Centrality \\
\hline 1 & Miller, D. (25) & Chrisman, J.J. & Chrisman, J.J. & Chrisman, J.J. \\
2 & Kellermanns, F.W. (19) & Chirico, F. & Chirico, F. & Miller, D. \\
3 & Chrisman, J.J. (17) & Miller, D. & Miller, D. & Chua, J.H. \\
4 & Le Breton-Miller, I. (15) & Nordqvist, M. & Nordqvist, M. & De Massis, A. \\
5 & De Massis, A. (12) & De Massis, A. & De Massis, A. & Le Breton-Miller, I. \\
\hline
\end{tabular}

The analysis of the top five authors based on the three network measures shows the important presence of authors in the research stream. For all three centralities, Chrisman J.J.'s papers have the highest centrality scores. The two important works by the number of citations are "Succession and nonsuccession concerns of family firms and agency relationship with nonfamily managers" published in the Family Business Review and "Are family managers agents or stewards? An exploratory study in privately held family firms" published in the Journal of Business Research. Chrisman J.J. publishes important papers that mainly deals with the relationship between family ownership and financing, family succession, and analytic views on family business literature. Chirico F., Nordqvist M., and Chua J.H. are not in the top five by frequency, but they have an important presence in terms of their connections with the research community. Among Chirico, F.'s work, "Family firm heterogeneity and governance: A configuration approach" published in the Journal of 
Small Business Management provides nine categories of family firm types that are useful in reflecting on the meaningful differences in ownership and management of family firms.

\section{Discussion}

This study aims to advance our understanding of the landscape of family governance research. Family involvement in a business has been suggested as an important factor that changes the goals or strategy of a firm. We conducted a systematic literature review using network analysis of keywords, citations, and authors.

By analyzing how the studies form research networks, this study provides several important implications for both theory and practice. First, we present a systematic overview of the broader family governance literature by adopting a network-based approach. Previous review papers either reviewed the general family firm research or focused narrowly on a specific dimension of family firms (e.g., succession $[15,16]$, internationalization [17], philanthropy [18], entrepreneurship [19], accounting practices [20], or institutional context [21,22]). Instead, we focused on three important network-related factors (i.e., keywords, citations, and authors) that are key to understanding the complete research network. By doing so, we offer an objective insight into the intellectual structure of the family governance research. We can thus present an overview of the structural characteristics of the keyword, citation, and author networks in the family governance literature. Therefore, we improve the understanding of how research on family governance is connected and which issues, papers, and authors have greater importance in connecting research. Except for studies that conduct a citation analysis, no existing systematic review provides such a comprehensive network analysis. The systematic approach that we adopt allowed us to remove any subjective perspective in conducting the literature review, as we were able to discover unobserved networks that existing studies are formulating [29].

Second, we offer a thorough insight into the research trend by reviewing an extensive pool of corporate governance research on family involvement. Given the lack of consensus on a definition of family firms [87], an important limitation of past reviews that use samples of family firms is that they depend considerably on how each researcher defines family firms based on their subjective criterion for family involvement. In this review, we included research that incorporates variables associated with family involvement in the corporate governance literature rather than limiting our scope to papers that deal with an explicit sample of family firms per se. We thereby examined all relevant research (947 papers), including studies omitted from previous analyses, and provide a truly comprehensive systematic analysis of the whole research network encompassing different business disciplines.

Third, our analysis reveals that the journals with the most articles do not necessarily produce the most cited articles. For instance, most influential papers in the citation network are published in the Journal of Financial Economics and the Journal of Finance, whereas Family Business Review has the greatest number of publications in the family governance literature. This result indicates the importance of family involvement in the general corporate governance literature, though specific implications for family involvement are largely explored in family firm-centered journals.

Finally, the findings of our systematic review suggest valuable implications for future research that provide meaningful guidelines for researchers in the field. For instance, our review answers important questions such as "which journals should I read?", "which keywords should I look for?", "who are the leading scholars?", "which journals are scholars publishing in?", and "what are emerging research trends?".

Our study is not without limitations that can be further explored in future research. First, the research trend in this study is based only on academic literature. However, future research may benefit from an analysis linking the real market or industry trend to the research trend, which can reveal insights on the differences and similarities between practitioners' and scholars' interests. Second, we analyzed a single source, research articles, to determine the research trend. In this regard, future research may consider other types 
of sources, such as books, newspapers, or conference proceedings to understand the community's perception of the corporate governance issues relevant to family ownership, thereby enhancing the understanding of the developmental history of family ownershiprelated discussion.

Author Contributions: Conceptualization, H.S.A. and H.C.; formal analysis, methodology, and validation, E.J.; writing — original draft preparation, H.S.A., H.C., and E.J.; writing-review and editing, H.S.A. and H.C.; funding acquisition, H.C.; project administration, E.J. All authors have read and agreed to the published version of the manuscript.

Funding: This research was supported by the Korea University Research Grant.

Conflicts of Interest: The authors declare no conflict of interest.

\section{References}

1. Khanna, T.; Palepu, K.G. Winning in emerging markets: A road map for strategy and execution. NHRD Netw. J. 2010, 3, 75. [CrossRef]

2. Douma, S.; George, R.; Kabir, R. Foreign and domestic ownership, business groups, and firm performance: Evidence from a large emerging market. Strateg. Manag. J. 2006, 27, 637-657. [CrossRef]

3. La Porta, R.; Lopez-de-Silanes, F.; Shleifer, A. Corporate ownership around the world. J. Financ. 1999, 54, 471-517. [CrossRef]

4. Villalonga, B.; Amit, R. How are U.S. family firms controlled? Rev. Financ. Stud. 2009, 22, 3047-3091. [CrossRef]

5. Faccio, M.; Lang, L.H. The ultimate ownership of Western European corporations. J. Financ. Econ. 2002, 65, 365-395. [CrossRef]

6. De Massis, A.; Frattini, F.; Majocchi, A.; Piscitello, L. Family firms in the global economy: Toward a deeper understanding of internationalization determinants, processes, and outcomes. Glob. Strat. J. 2018, 8, 3-21. [CrossRef]

7. Anderson, R.; Reeb, D.M. Founding-family ownership and firm performance: Evidence from the S\&P 500. J. Financ. 2003, 58, 1301-1328. [CrossRef]

8. Zahra, S.A.; Sharma, P. Family business research: A strategic reflection. Fam. Bus. Rev. 2004, 17, 331-346. [CrossRef]

9. Family Firm Institute: Global Data Point. Available online: http://www.ffi.org/page/globaldatapoints (accessed on 21 December 2020).

10. Daily, C.M.; Dalton, D.R.; Cannella, A.A., Jr. Corporate governance: Decades of dialogue and data. Acad. Manag. Rev. 2003, 28, 371-382. [CrossRef]

11. Xi, J.; Kraus, S.; Filser, M.; Kellermanns, F. Mapping the field of family business research: Past trends and future directions. Int. Entrep. Manag. J. 2015, 11, 113-132. [CrossRef]

12. Bird, B.; Welsch, H.; Astrachan, J.H.; Pistrui, D. Family business research: The evolution of an academic field. Fam. Bus. Rev. 2002, 15, 337-350. [CrossRef]

13. Evert, R.E.; Martin, J.A.; McLeod, M.S.; Payne, G.T. Empirics in family business research: Progress, challenges, and the path ahead. Fam. Bus. Rev. 2016, 29, 17-43. [CrossRef]

14. Handler, W.C. Methodological issues and considerations in studying family businesses. Fam. Bus. Rev. 1989, 2, 257-276. [CrossRef]

15. Handler, W.C. Succession in family business: A review of the research. Fam. Bus. Rev. 1994, 7, 133-157. [CrossRef]

16. Daspit, J.J.; Holt, D.T.; Chrisman, J.J.; Long, R.G. Examining family firm succession from a social exchange perspective: A multiphase, multistakeholder review. Fam. Bus. Rev. 2016, 29, 44-64. [CrossRef]

17. Pukall, T.J.; Calabro, A. The internationalization of family firms: A critical review and integrative model. Fam. Bus. Rev. 2014, 27, 103-125. [CrossRef]

18. Feliu, N.; Botero, I.C. Philanthropy in family enterprises: A review of literature. Fam. Bus. Rev. 2016, 29, 121-141. [CrossRef]

19. Goel, S.; Jones, R.J., III. Entrepreneurial exploration and exploitation in family business: A systematic review and future directions. Fam. Bus. Rev. 2016, 29, 94-120. [CrossRef]

20. Salvato, C.; Moores, K. Research on accounting in family firms: Past accomplishments and future challenges. Fam. Bus. Rev. 2010, 23, 193-215. [CrossRef]

21. Soleimanof, S.; Rutherford, M.W.; Webb, J.W. The intersection of family firms and institutional contexts: A review and agenda for future research. Fam. Bus. Rev. 2017, 31, 32-53. [CrossRef]

22. Young, M.N.; Peng, M.W.; Ahlstrom, D.; Bruton, G.D.; Jiang, Y. Corporate governance in emerging economies: A review of the principal-principal perspective. J. Manag. Stud. 2008, 45, 196-220. [CrossRef]

23. Nerur, S.; Rasheed, A.A.; Natarajan, V. The intellectual structure of the strategic management field: An author co-citation analysis. Strat. Manag. J. 2008, 29, 319-336. [CrossRef]

24. Fan, D.; Lo, C.K.; Ching, V.; Kan, C. Occupational health and safety issues in operations management: A systematic and citation network analysis review. Int. J. Prod. Econ. 2014, 158, 334-344. [CrossRef]

25. Colicchia, C.; Strozzi, F. Supply chain risk management: A new methodology for a systematic literature review. Supply Chain Manag. 2012, 17, 403-418. [CrossRef]

26. Short, J.C.; Sharma, P.; Lumpkin, G.; Pearson, A.W. Oh, the places we'll go! Reviewing past, present, and future possibilities in family business research. Fam. Bus. Rev. 2016, 29, 11-16. [CrossRef] 
27. Oh, W.; Choi, J.N.; Kim, K. Coauthorship dynamics and knowledge capital: The patterns of cross-disciplinary collaboration in information systems research. J. Manag. Inf. Syst. 2005, 22, 266-292. [CrossRef]

28. Choi, J.; Yi, S.; Lee, K. Analysis of keyword networks in MIS research and implications for predicting knowledge evolution. Inf. Manag. 2011, 48, 371-381. [CrossRef]

29. Ramos-Rodríguez, A.R.; Ruíz-Navarro, J. Changes in the intellectual structure of strategic management research: A bibliometric study of the Strategic Management Journal, 1980-2000. Strat. Manag. J. 2004, 25, 981-1004. [CrossRef]

30. Tranfield, D.; Denyer, D.; Smart, P. Towards a methodology for developing evidence-informed management knowledge by means of systematic review. Br. J. Manag. 2003, 14, 207-222. [CrossRef]

31. Mentzer, J.T.; Kahn, K.B. A framework of logistics research. Journal of Business Logistics. J. Bus. Logist. 1995, 16, 231.

32. Ord, T.J.; Martins, E.P.; Thakur, S.; Mane, K.K.; Börner, K. Trends in animal behaviour research (1968-2002): Ethoinformatics and the mining of library databases. Anim. Behav. 2005, 69, 1399-1413. [CrossRef]

33. Rey-Martí, A.; Ribeiro-Soriano, D.; Palacios-Marqués, D. A bibliometric analysis of social entrepreneurship. J. Bus. Res. 2016, 69, 1651-1655. [CrossRef]

34. De Bakker, F.G.A.; Groenewegen, P.; den Hond, F. A bibliometric analysis of 30 years of research and theory on corporate social responsibility and corporate social performance. Bus. Soc. 2005, 44, 283-317. [CrossRef]

35. López-Fernández, M.C.; Serrano-Bedia, A.M.; Pérez-Pérez, M. Entrepreneurship and family firm research: A bibliometric analysis of an emerging field. J. Small Bus. Manag. 2016, 54, 622-639. [CrossRef]

36. Park, J.; Jeong, E. Service quality in tourism: A systematic literature review and keyword network analysis. Sustainability 2019, 11, 3665. [CrossRef]

37. Ding, Y.; Cronin, B. Popular and/or prestigious? Measures of scholarly esteem. Inf. Process. Manag. 2011, 47, 80-96. [CrossRef]

38. White, H.D.; Griffith, B.C. Author cocitation: A literature measure of intellectual structure. J. Am. Soc. Inf. Sci. 1981, 32, 163-171. [CrossRef]

39. Shiau, W.-L.; Chen, S.-Y.; Tsai, Y.-C. Management information systems issues: Co-citation analysis of journal articles. Int. J. Electron. Commer. Stud. 2015, 6, 145-162. [CrossRef]

40. Culnan, M.J. The intellectual development of management information systems, 1972-1982: A co-citation analysis. Manag. Sci. 1986, 32, 156-172. [CrossRef]

41. Pilkington, A.; Meredith, J. The evolution of the intellectual structure of operations management-1980-2006: A citation/cocitation analysis. J. Oper. Manag. 2009, 27, 185-202. [CrossRef]

42. Choi, A.S.; Ritchie, B.W.; Papandrea, F.; Bennett, J. Economic valuation of cultural heritage sites: A choice modeling approach. Tour. Manag. 2010, 31, 213-220. [CrossRef]

43. Dotsika, F.; Watkins, A. Identifying potentially disruptive trends by means of keyword network analysis. Technol. Forecast. Soc. Chang. 2017, 119, 114-127. [CrossRef]

44. Brin, S.; Page, L. The anatomy of a large-scale hypertextual Web search engine. Comput. Netw. ISDN Syst. 1998, 30, 107-117. [CrossRef]

45. Kim, W.; Khan, G.F.; Wood, J.; Mahmood, M.T. Employee engagement for sustainable organizations: Keyword analysis using social network analysis and burst detection approach. Sustainability 2016, 8, 631. [CrossRef]

46. Yoo, S.; Jang, S.; Byun, S.W.; Park, S. Exploring human resource development research themes: A keyword network analysis. Hum. Resour. Dev. Q. 2018, 30, 155-174. [CrossRef]

47. Hage, P.; Harary, F. Exchange in Oceania: A Graph Theoretic Analysis; Oxford University Press: Oxford, UK, 1991.

48. Hunt, T.L. Graphic theoretic network models for Lapita exchange: A trial application. In Archaeology of the Lapita Cultural Complex: A Critical Review; Kirch, P.V., Hunt, T.L., Eds.; Thomas Burke Memorial Washington State Museum Research Reports no. 5: Seattle, WA, USA, 1988.

49. Irwin, G. Chieftainship, kula and trade in Massim prehistory. In The Kula: New Perspectives on Massim Exchange; Leach, J.W., Leach, E.R., Eds.; Cambridge University Press: Cambridge, UK, 1983.

50. Kirch, P.V. Niautoputapu: The Prehistory of a Polynesian Chiefdom, 1st ed.; Burke Museum: Seattle, WA, USA, 1988.

51. Brandes, U. A faster algorithm for betweenness centrality. J. Math. Sociol. 2001, 25, 163-177. [CrossRef]

52. Newman, M.J. A measure of betweenness centrality based on random walks. Soc. Netw. 2005, 27, 39-54. [CrossRef]

53. Borgatti, S.P.; Everett, M.G. A graph-theoretic perspective on centrality. Soc. Netw. 2006, 28, 466-484. [CrossRef]

54. Freeman, L.C. Centrality in social networks conceptual clarification. Soc. Netw. 1978, 1, 215-239. [CrossRef]

55. Terlaak, A.; Kim, S.; Roh, T. Not good, not bad: The effect of family control on environmental performance disclosure by business group firms. J. Bus. Ethics 2018, 153, 977-996. [CrossRef]

56. Gomez-Mejia, L.R.; Cruz, C.; Berrone, P.; De Castro, J. The bind that ties: Socioemotional wealth preservation in family firms. Acad. Manag. Ann. 2011, 5, 653-707. [CrossRef]

57. Gómez-Mejía, L.R.; Haynes, K.T.; Núñez-Nickel, M.; Jacobson, K.J.L.; Moyano-Fuentes, J. Socioemotional wealth and business risks in family-controlled firms: Evidence from Spanish olive oil mills. Adm. Sci. Q. 2007, 52, 106-137. [CrossRef]

58. Sharma, P. An overview of the field of family business studies: Current status and directions for the future. Fam. Bus. Rev. 2004, 17, 1-36. [CrossRef]

59. Minichilli, A.; Brogi, M.; Calabrò, A. Weathering the storm: Family ownership, governance, and performance through the financial and economic crisis. Corp. Gov. Int. Rev. 2015, 24, 552-568. [CrossRef] 
60. Crespí-Cladera, R.; Martín-Oliver, A. Do family firms have better access to external finance during crises? Corp. Gov. Int. Rev. 2015, 23, 249-265. [CrossRef]

61. Madison, K.; Holt, D.T.; Kellermanns, F.W.; Ranft, A.L. Viewing family firm behavior and governance through the lens of agency and stewardship theories. Fam. Bus. Rev. 2016, 29, 65-93. [CrossRef]

62. Gedajlovic, E.; Carney, M.; Chrisman, J.J.; Kellermanns, F.W. The adolescence of family firm research: Taking stock and planning for the future. J. Manag. 2012, 38, 1010-1037. [CrossRef]

63. Eddleston, K.A.; Kellermanns, F.W. Destructive and productive family relationships: A stewardship theory perspective. J. Bus. Ventur. 2007, 22, 545-565. [CrossRef]

64. Le Breton-Miller, I.; Miller, D. Agency vs. stewardship in public family firms: A social embeddedness reconciliation. Entrep. Theory Pr. 2009, 33, 1169-1191. [CrossRef]

65. Zahra, S.A.; Hayton, J.C.; Neubaum, D.O.; Dibrell, C.; Craig, J.B. Culture of family commitment and strategic flexibility: The moderating effect of stewardship. Entrep. Theory Pr. 2008, 32, 1035-1054. [CrossRef]

66. Rondi, E.; De Massis, A.; Kotlar, J. Unlocking innovation potential: A typology of family business innovation postures and the critical role of the family system. J. Fam. Bus. Strategy 2019, 10, 100236. [CrossRef]

67. Davis, J.H.; Schoorman, F.D.; Donaldson, L. Toward a stewardship theory of management. Acad. Manag. Rev. 1997, 22, 20-47. [CrossRef]

68. Gomez-Mejia, L.R.; Makri, M.; Kintana, M.L. Diversification decisions in family-controlled firms. J. Manag. Stud. 2010, 47, 223-252 [CrossRef]

69. Zellweger, T.M.; Kellermanns, F.W.; Chrisman, J.J.; Chua, J.H. Family control and family firm valuation by family CEOs: The importance of intentions for transgenerational control. Organ. Sci. 2012, 23, 851-868. [CrossRef]

70. Bertrand, M.; Schoar, A. The role of family in family firms. J. Econ. Perspect. 2006, 20, 73-96. [CrossRef]

71. Fahimnia, B.; Sarkis, J.; Davarzani, H. Green supply chain management: A review and bibliometric analysis. Int. J. Prod. Econ. 2015, 162, 101-114. [CrossRef]

72. Khitous, F.; Strozzi, F.; Urbinati, A.; Alberti, F. A systematic literature network analysis of existing themes and emerging research trends in circular economy. Sustainability 2020, 12, 1633. [CrossRef]

73. Hummon, N.P.; Dereian, P. Connectivity in a citation network: The development of DNA theory. Soc. Netw. 1989, 11, 39-63. [CrossRef]

74. Gundolf, K.; Filser, M. Management research and religion: A citation analysis. J. Bus. Ethics 2012, 112, 177-185. [CrossRef]

75. Morck, R.; Shleifer, A.; Vishny, R.W. Management ownership and market valuation: An empirical analysis. J. Financ. Econ. 1988, 20, 293-315. [CrossRef]

76. DeAngelo, H.; DeAngelo, L. Managerial ownership of voting rights: A study of public corporations with dual classes of common stock. J. Financ. Econ. 1985, 14, 33-69. [CrossRef]

77. Claessens, S.; Djankov, S.; Lang, L.H. The separation of ownership and control in East Asian corporations. J. Financ. Econ. 2000, 58, 81-112. [CrossRef]

78. Villalonga, B.; Amit, R. How do family ownership, control and management affect firm value? J. Financ. Econ. 2006, 80, 385-417. [CrossRef]

79. Astrachan, J.H.; Kolenko, T.A. A neglected factor explaining family business success: Human resource practices. Fam. Bus. Rev. 1994, 7, 251-262. [CrossRef]

80. Litz, R.A. The family business: Toward definitional clarity. Fam. Bus. Rev. 1995, 8, 71-81. [CrossRef]

81. Gomez-Mejia, L.R.; Larraza-Kintana, M.; Makri, M. The determinants of executive compensation in family-controlled public corporations. Acad. Manag. J. 2003, 46, 226-237.

82. Chua, J.H.; Chrisman, J.J.; Sharma, P. Succession and nonsuccession concerns of family firms and agency relationship with nonfamily managers. Fam. Bus. Rev. 2003, 16, 89-107. [CrossRef]

83. Miller, D.; Steier, L.; Le Breton-Miller, I. Lost in time: Intergenerational succession, change, and failure in family business. J. Bus. Ventur. 2003, 18, 513-531. [CrossRef]

84. Daily, C.M.; Dollinger, M.J. An empirical examination of ownership structure in family and professionally managed firms. Fam. Bus. Rev. 1992, 5, 117-136. [CrossRef]

85. Schulze, W.S.; Lubatkin, M.H.; Dino, R.N. Toward a theory of agency and altruism in family firms. J. Bus. Ventur. 2003, 18, 473-490. [CrossRef]

86. Miller, D.; Le Breton-Miller, I.; Lester, R.H.; Cannella, A.A., Jr. Are family firms really superior performers? J. Corp. Financ. 2007, 13, 829-858. [CrossRef]

87. Dyer, W.G. Examining the "family effect" on firm performance. Fam. Bus. Rev. 2006, 19, 253-273. [CrossRef] 